
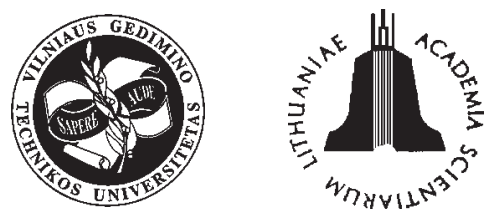

JOURNAL OF CIVIL ENGINEERING AND MANAGEMENT

http:/www.jcem.vgtu.lt

2005, Vol XI, No 2, 145-151

\title{
DEFORMATIONAL ANALYSIS OF PRESTRESSED HIGH-STRENGTH CONCRETE MEMBERS USING FLEXURAL CONSTITUTIVE MODEL
}

\author{
Renata Zamblauskaitė, Gintaris Kaklauskas and Darius Bacinskas \\ Dept of Bridges and Special Structures, Vilnius Gediminas Technical University, \\ Sauletekio al. 11, LT-10223 Vilnius, Lithuania. E-mail: bridge@st.vtu.lt
}

Received 07 March 2005; accepted 04 May 2005

\begin{abstract}
In this paper, an attempt has been made to extend application of the recently proposed Flexural constitutive model to short- and long-term deformational analysis of flexural partially prestressed concrete members. The effect of tension stiffening and non-linear time effects of creep and shrinkage are taken into account. Effective modulus method is used for modelling long-term deformations. The proposed calculation technique is based on the layered approach and use of material stress-strain relationships. Curvatures prediction results were tested against experimental data of partially prestressed concrete beams reported in literature.
\end{abstract}

Keywords: creep, shrinkage, partial prestressing, prestress loss, tension stiffening, flexure, curvature.

\section{Introduction}

Partially prestressed concrete, combining tensioned and untensioned reinforcement, is a general case of structural concrete. The effect of non-tensioned steel in reducing time-dependent camber of prestressed concrete beams is similar to the effect of compressive reinforcement in reducing long-term deflections of ordinary reinforced concrete members. The prestress losses due to creep decrease with a decrease in the partial prestressing ratio.

Long-term deformations of reinforced (non-prestressed), prestressed and partially prestressed concrete structures might be several times larger than elastic deformations. Such increments are caused by complex physical effects such as concrete creep, shrinkage and cracking, bond between steel and concrete, etc. Design engineers for both short- and long-term deformational analysis of reinforced (non-prestressed), prestressed and partially prestressed concrete structures can use either empirical code [1-4] or numerical methods [5-7].

Different techniques are used for strength, deflection, prestress losses and crack width analysis. Typically, methods for calculating prestress losses, which are widely available in the literature $[2,3]$, do not account for the presence of non-prestressed reinforcement in partially prestressed concrete members. Most importantly, due to their simplicity the code methods cannot include many geometrical and physical parameters and, therefore, are not accurate enough. Numerical methods [5-7] are based on universal principles and can take into account all possible material effects.
A constitutive model, called the Flexural, has been developed for deformational analysis of flexural reinforced concrete members subjected to short-term loading $[8,9]$. This model consists of traditional constitutive relationships for reinforcement and compressive concrete.

The most important part of this model is a constitutive relationship for cracked tensile concrete which accumulates cracking, tension stiffening, reinforcement slippage and shrinkage effects. Further, the Flexural constitutive model has been applied for long-term deformational analysis of reinforced $[10,11]$ as well as deformational analysis of flexural prestressed concrete structures [12].

In this paper, a simplified approach to computing instantaneous and long-term deformations of cracked reinforced (non-prestressed), prestressed and partially prestressed concrete members has been proposed. Acceptability of the technique was checked by estimating time deformations of experimental partially prestressed concrete members reported in literature.

\section{Stress-strain relationships for concrete and rein- forcement}

The present analysis method is based on the classical techniques of strength of materials extended to application of the layered approach and the use of the materials diagrams of the Flexural constitutive model [9].

Modelling of compressive and tensile concrete. For both short- and long-term analysis, the stress-strain relationships for the compressive and tensile concrete are shown in Fig 1. The ascending branch of the compressive concrete diagram has the following expression: 


$$
\left\{\begin{array}{l}
\sigma_{c}\left(t_{0}\right)=f_{c, \text { max }}\left(t_{0}\right)\left\{\frac{2 \varepsilon_{c}\left(t_{0}\right)}{\varepsilon_{0}\left(t_{0}\right)}-\left(\frac{\varepsilon_{c}\left(t_{0}\right)}{\varepsilon_{0}\left(t_{0}\right)}\right)^{2}\right\}, \\
\sigma_{c}\left(t, t_{0}\right)=f_{c, \text { max }}\left(t, t_{0}\right)\left\{\frac{2 \varepsilon_{c}\left(t, t_{0}\right)}{\varepsilon_{0}\left(t, t_{0}\right)}-\left(\frac{\varepsilon_{c}\left(t, t_{0}\right)}{\varepsilon_{0}\left(t, t_{0}\right)}\right)^{2}\right\},
\end{array}\right.
$$

here $t_{0}$ is time at first loading (or prestressing) (in days); $t$ - time under consideration (in days); $\sigma_{c}\left(t_{0}\right)$, $\sigma_{c}\left(t, t_{0}\right)$ - the compressive stresses; $f_{c, \max }\left(t_{0}\right)$ and $\varepsilon_{0}\left(t_{0}\right), f_{c, \text { max }}\left(t, t_{0}\right)$ and $\varepsilon_{0}\left(t, t_{0}\right)-$ the maximum compressive stresses and the corresponding strains for shortand long- term loading, respectively:

$$
\left\{\begin{array} { l } 
{ \varepsilon _ { 0 } ( t _ { 0 } ) = \frac { 2 f _ { c , \text { max } } ( t _ { 0 } ) } { E _ { c } ( t _ { 0 } ) } , } \\
{ \varepsilon _ { 0 } ( t , t _ { 0 } ) = \frac { 2 f _ { c , \text { max } } ( t , t _ { 0 } ) } { E _ { e } ( t , t _ { 0 } ) } , }
\end{array} \left\{\begin{array}{l}
\varepsilon_{u}\left(t_{0}\right)=1,9 \varepsilon_{0}\left(t_{0}\right), \\
\varepsilon_{u}\left(t, t_{0}\right)=1,9 \varepsilon_{0}\left(t, t_{0}\right) .
\end{array}\right.\right.
$$

It is well known that strength of compressive concrete varies with time [13]. Structural defects initiated by hardening of concrete develop with time and cause reduction of compressive strength. On the other hand, concrete strength increases with time due to hydration of cement.

In the present study, these effects are accounted for factors $\beta_{c c}$ and $\beta_{c, \text { sus }}$ given in CEB-FIB Model Code 1990 [4].

The maximum compressive stress $f_{c, \text { max }}(t)$ at any time $t$ is determined as follows:

$$
f_{c, \max }\left(t, t_{0}\right)=f_{c}(28) \beta_{c c}(t) \beta_{c, \text { sus }}\left(t, t_{0}\right),
$$

where $f_{c}(28)$ is short-term compressive strength (at time $t_{0}=28$ days); $\beta_{c c}(t)$ - the factor assessing influence of cement hydration process on compressive strength of con- crete and $\beta_{c, \text { sus }}\left(t, t_{0}\right)$ - the factor accounting for microcracking effects on concrete strength and are expressed as:

$$
\begin{gathered}
\beta_{c c}(t)=\exp \left\{s\left[1-\left(\frac{28}{t}\right)^{0.5}\right]\right\}, \\
\beta_{c, \text { sus }}\left(t, t_{0}\right)=0,96-0,12\left\{\ln \left[72\left(t-t_{0}\right)\right]\right\}^{0.5},
\end{gathered}
$$

where $s$ is the coefficient depending on the cement type [2].

The effective modulus of elasticity of concrete $E_{e}\left(t, t_{0}\right)$ for modelling the effects of creep in concrete is expressed as:

$$
E_{e}\left(t, t_{0}\right)=\frac{E_{c}\left(t_{0}\right)}{1+\phi\left(t, t_{0}\right)},
$$

where $E_{c}\left(t_{0}\right)$ is the modulus of elasticity of concrete at time $t_{0} ; \phi\left(t, t_{0}\right)$ - the creep coefficient at time $t$ for concrete loaded at $t_{0}$.

In the present analysis, the Flexural constitutive relationship [8-10] has been used for modelling short- and long-term behaviour of cracked tensile concrete. The descending branches of the tensile concrete diagrams shown in Fig 2 have the following expressions:

$$
\left\{\begin{aligned}
f_{t}\left(t_{0}\right)= & 0,625 f_{c r}\left(t_{0}\right) \times \\
\times & \left\{1-\frac{\overline{\varepsilon_{t}}\left(t_{0}\right)}{\beta\left(t_{0}\right)}+\frac{1+0,6 \beta\left(t_{0}\right)}{\beta \overline{\varepsilon_{t}}\left(t_{0}\right)}\right\}, \\
f_{t}\left(t, t_{0}\right) & =0,625 f_{c r}\left(t, t_{0}\right) \times \\
& \times\left\{1-\frac{\overline{\varepsilon_{t}}\left(t, t_{0}\right)}{\beta\left(t, t_{0}\right)}+\frac{1+0,6 \beta\left(t, t_{0}\right)}{\beta \overline{\varepsilon_{t}}\left(t, t_{0}\right)}\right\},
\end{aligned}\right.
$$

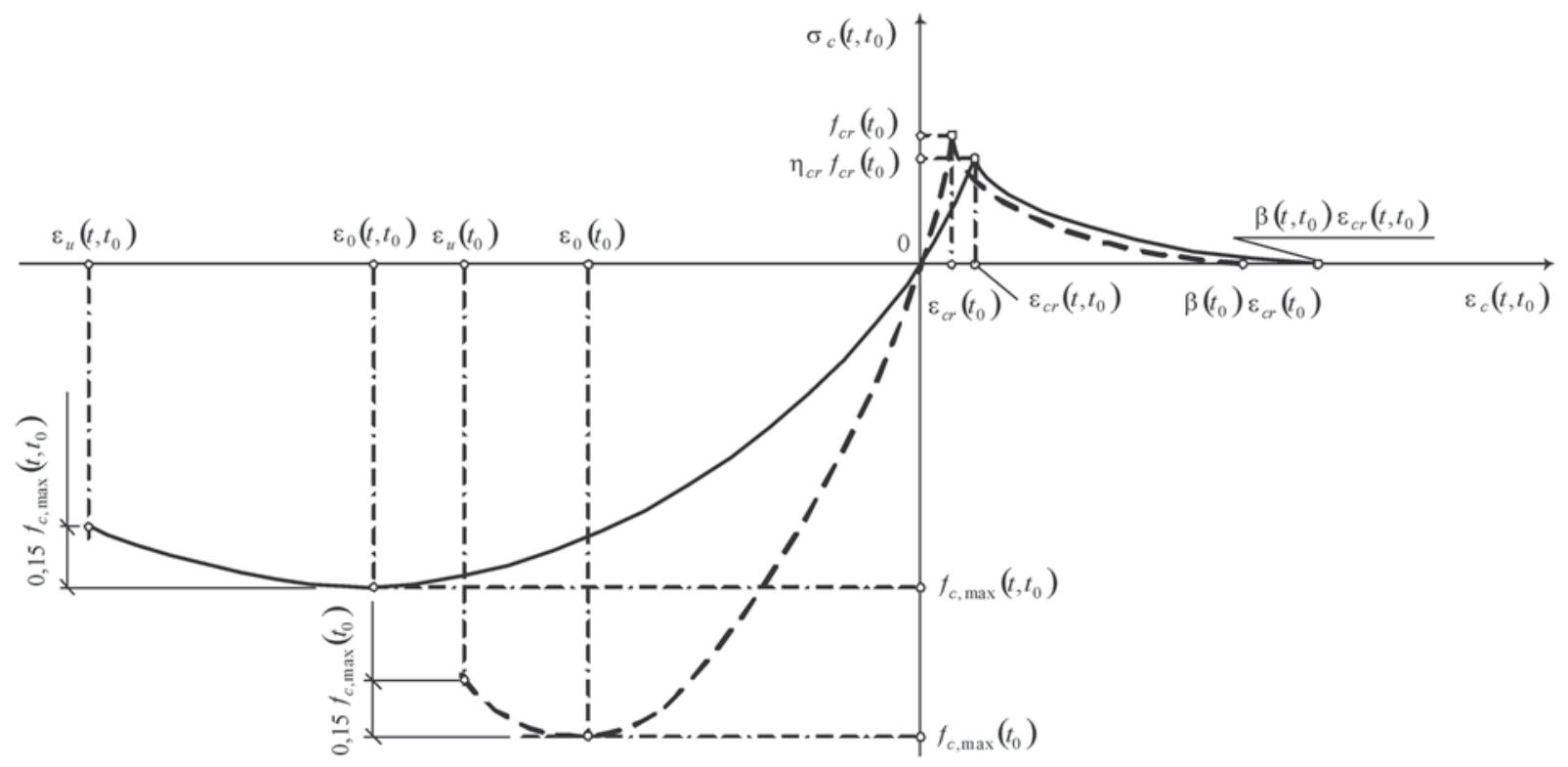

Fig 1. Stress-strain relationships for compressive and tensile concrete long-term loading 


$$
\left\{\begin{array} { l } 
{ \overline { \varepsilon } ( t _ { 0 } ) = \frac { \varepsilon _ { t } ( t _ { 0 } ) } { \varepsilon _ { c r } ( t _ { 0 } ) } , } \\
{ \overline { \varepsilon } ( t , t _ { 0 } ) = \frac { \varepsilon _ { t } ( t , t _ { 0 } ) } { \varepsilon _ { c r } ( t , t _ { 0 } ) } , }
\end{array} \quad \left\{\begin{array}{l}
\varepsilon_{c r}\left(t_{0}\right)=\frac{f_{c r}\left(t_{0}\right)}{E_{c}\left(t_{0}\right)}, \\
\varepsilon_{c r}\left(t, t_{0}\right)=\frac{f_{c r}\left(t, t_{0}\right)}{E_{e}\left(t, t_{0}\right)},
\end{array}\right.\right.
$$

where $f_{c r}\left(t_{0}\right), f_{c r}\left(t, t_{0}\right)$ are the short- and long-term strength of tensile concrete, respectively; $\overline{\varepsilon_{t}}\left(t_{0}\right)$ and $\varepsilon_{c r}\left(t_{0}\right), \overline{\varepsilon_{t}}\left(t, t_{0}\right)$ and $\varepsilon_{c r}\left(t, t_{0}\right)$ - the strain and the cracking strain of tensile concrete at time $t_{0}$ and $t$, respectively.

The factors $\beta\left(t_{0}\right), \beta\left(t, t_{0}\right)$ describing the length of the descending branch of the constitutive relationship for short- [8] and long- [10] term loading (Fig 2), respectively, are expressed as:

$$
\begin{gathered}
\beta\left(t_{0}\right)=32,8-27,6 p+7,12 p^{2}, \\
\beta\left(t, t_{0}\right)=\frac{\beta\left(t_{0}\right)}{\eta_{c r}^{2}\left[1+\phi\left(t, t_{0}\right)\right]},
\end{gathered}
$$

where $p$ is the reinforcement percentage; $\beta\left(t_{0}\right)=5$, if $p \geq 2 \%$.

The factor $\eta_{c r}$ describing the concrete tensile strength reduction due to sustained loading [14] is obtained from the following expression:

$$
\eta_{c r}=\frac{f_{c r}\left(t, t_{0}\right)}{f_{c r}\left(t_{0}\right)}=0,794-0,06 \log \left(t-t_{0}\right) .
$$

Modelling of reinforcement. For reinforcement material idealization, a bilinear, trilinear or more complex stress-strain relationship can be adopted. The stress-strain curve for the long-term analysis is taken the same as for the short-term one, ie no creep is assumed in the steel.

\section{Short- and long-term deformation analysis of par- tially prestressed concrete members}

In this section, a method for short-and long- term deformational analysis of flexural partially prestressed concrete members is being proposed.
As shown in Fig 3, $a$ and $b, a$ member may contain multiple levels of both prestressed and non-prestressed reinforcement. The member's cross-section is divided into a number of horizontal layers corresponding to either concrete or reinforcement (Fig 3,c).

The non-linear material properties are assessed in iterative calculation by means of secant deformation modulus. The cross-section analysis is performed in the so-called transformed section.

The proposed calculation technique is based on the following approaches and assumptions: 1) smeared crack approach; 2) linear distribution of strain within the depth of the section; 3) perfect bond between concrete and reinforcement; 4) effective modulus method based on effective modulus of concrete elasticity, is used for modelling the effects of creep in concrete; 5) uniform concrete shrinkage within the section depth.

Longitudinal strain $\varepsilon_{j}^{i}\left(t, t_{0}\right)$ in every layer $i$ (Fig 3, $c, d)$ is taken as:

$$
\varepsilon_{j}^{i}\left(t, t_{0}\right)=\varepsilon_{c}^{T}\left(t, t_{0}\right)+y_{j}^{i} \kappa\left(t, t_{0}\right)-\varepsilon_{s h r}\left(t, t_{0}\right),
$$

where $y_{j}^{i}$ is the distance of the $i$-th layer from the top edge; $\varepsilon_{s h r}\left(t, t_{0}\right)$ - the concrete free shrinkage strain; $\varepsilon_{c}^{T}\left(t, t_{0}\right)$ and $\kappa\left(t, t_{0}\right)$ are the top fibre strain and curvature, respectively, obtained from the following expressions:

$$
\begin{gathered}
\varepsilon_{c}^{T}\left(t, t_{0}\right)=\frac{-S_{e}^{T} F_{1}-I_{e}^{T} F_{2}}{E_{e}\left(t, t_{0}\right)\left(A_{e} I_{e}^{T}-\left(S_{e}^{T}\right)^{2}\right)}, \\
\kappa\left(t, t_{0}\right)=\frac{A_{e} F_{1}+S_{e}^{T} F_{2}}{E_{e}\left(t, t_{0}\right)\left(A_{e} I_{e}^{T}-\left(S_{e}^{T}\right)^{2}\right)}, \\
F_{1}=M-P d_{n}+M_{s h r}\left(t, t_{0}\right), \\
F_{2}=P+N_{s h r}\left(t, t_{0}\right), \\
N_{s h r}\left(t, t_{0}\right)=-A_{c} E_{e}\left(t, t_{0}\right) \varepsilon_{s h r}\left(t, t_{0}\right),
\end{gathered}
$$

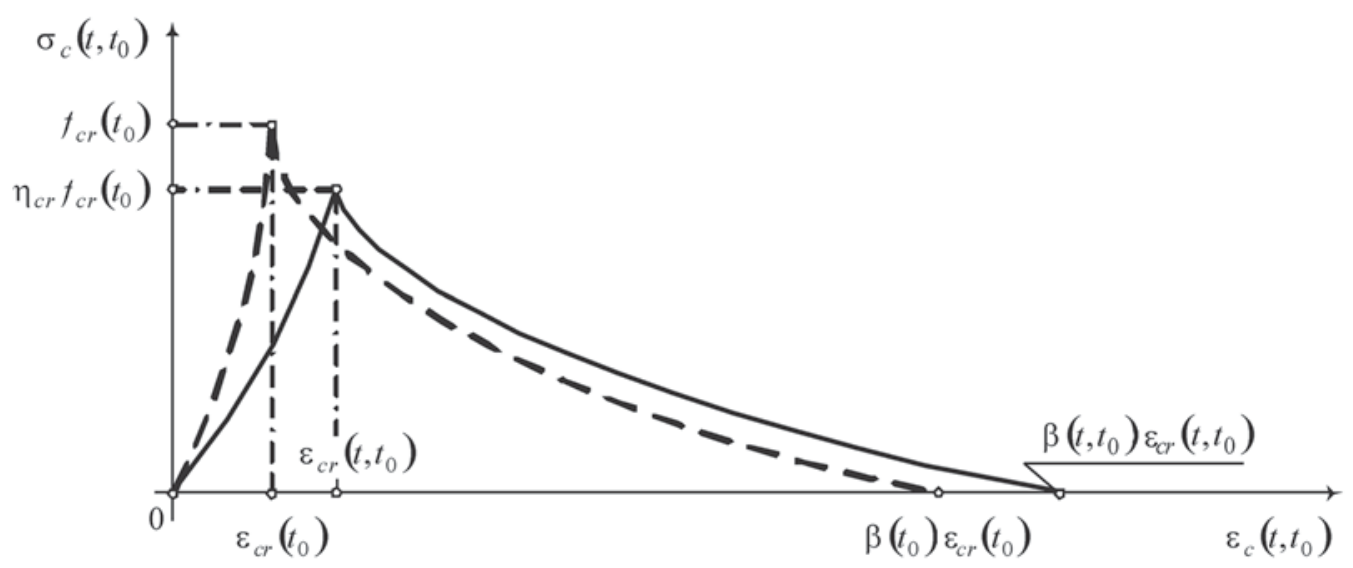

Fig 2. Stress-strain relationships for tensile concrete (__ $)$ - for short-term loading; (_ _ _ - ) - for long-term loading 


$$
M_{s h r}\left(t, t_{0}\right)=S_{c}^{T} E_{e}\left(t, t_{0}\right) \varepsilon_{s h r}\left(t, t_{0}\right),
$$

where $P$ is the initial prestressing force; $d_{n}$ - the distance from the initial prestressing force to the top surface; $M$ - the applied bending moment; $A_{e}$ - the transformed section area; $S_{e}^{T}$ and $I_{e}^{T}$ - the first and second moments of the area (about the top edge) given by the expressions:

$$
\left\{\begin{array}{l}
A_{e}=\sum_{i=1}^{n} b_{j}^{i} t_{j}^{i} \frac{E_{i}}{E_{e}\left(t, t_{0}\right)}, \\
S_{e}^{T}=\sum_{i=1}^{n} b_{j}^{i} t_{j}^{i} y_{j}^{i} \frac{E_{i}}{E_{e}\left(t, t_{0}\right)}, \\
I_{e}^{T}=\sum_{i=1}^{n}\left(\frac{b_{j}^{i}\left(t_{j}^{i}\right)^{3}}{12}+b_{j}^{i} t_{j}^{i}\left(y_{j}^{i}\right)^{2}\right) \frac{E_{i}}{E_{e}\left(t, t_{0}\right)},
\end{array}\right.
$$

$b_{j}^{i}$ and $t_{j}^{i}$ are the width and thickness of the $i$-th layer $(i=1,2 \ldots n)$, respectively; $A_{c}$ and $S_{c}-$ similar characteristics calculated for the concrete section ignoring the steel; $N_{s h r}\left(t, t_{0}\right)$ and $M_{s h r}\left(t, t_{0}\right)$ - the external force and the moment due to concrete free shrinkage strain $\varepsilon_{s h r}\left(t, t_{0}\right)$, respectively. It should be noted that taking $E_{c}\left(t_{0}\right)$ instead of $E_{e}\left(t, t_{0}\right)$ and $\varepsilon_{s h r}\left(t, t_{0}\right)=0$, the procedure can be applied to short-term deformation analysis.

The stress change in the prestressed reinforcement after transfer is obtained from the equation:

$$
\Delta \sigma_{s p}^{i}\left(t_{0}\right)=E_{s p}^{i}\left[\varepsilon_{c}^{T}\left(t_{0}\right)+y_{j}^{i} \kappa\left(t_{0}\right)\right],
$$

where $E_{s p}^{i}$ is the elasticity modulus of prestressed reinforcement.

The time-dependent loss of prestressing due to shrinkage and creep is given by:

a)

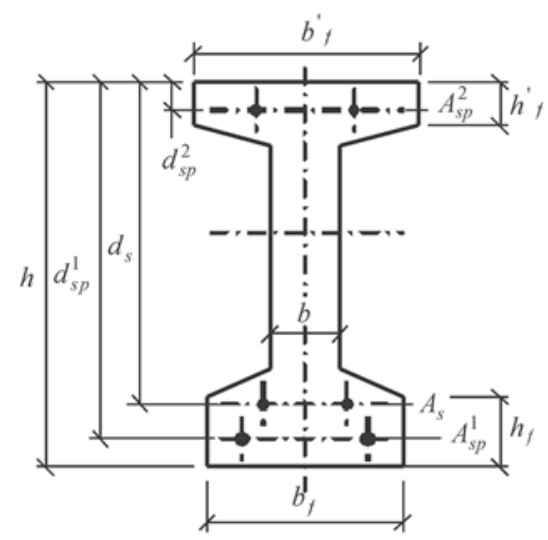

$\Delta \sigma_{s p}^{i}\left(t, t_{0}\right)=E_{s p}^{i}\left(\varepsilon_{c}^{T}\left(t, t_{0}\right)+y_{j}^{i} \kappa\left(t, t_{0}\right)\right)-\Delta \sigma_{s p}^{i}\left(t_{0}\right)$.

A computer program has been developed for calculating curvatures, deflections, and the stress and strain state of the member.

\section{Comparison with test data}

In this section, results of short- and long-term deformations and curvatures calculated by the method proposed are compared with experimental data of eight partially prestressed concrete beams reported by Sato et al. $[15,16]$. The experimental program $[15,16]$ was devoted to investigations of the differences between partially prestressed high-strength concrete members (PRHSC) and partially prestressed middle-strength concrete members (PRMSC).

For this purpose, four partially prestressed high strength (HL20, HL22, HL30, HL32) and the same number of partially prestressed middle strength (ML20, ML22, ML30, ML32) members were made. It is to be noted, that PRHSC members were subjected to the effect of autogenous shrinkage, then prestressed and, thereafter, loaded.

Main characteristics of the experimental beams and properties of concrete are presented in Table 1 and 2, respectively. Four members were provided with compression reinforcement. All specimens were demoulded at the age of 1 day for high-strength concrete and 5 days for middle-strength concrete.

The beams were nominally $2,20 \mathrm{~m}$ long, $250 \mathrm{~mm}$ high and $200 \mathrm{~mm}$ wide. All specimens were prestressed on the 9th day. On the 16th day, they were subjected to a long-term loading under two-point system. The members were accepted to crack under a sustained load.

In the long-term analysis, the proposed technique employs the characteristics of concrete creep factor and shrinkage strain taken from the experiments $[15,17,18]$.

c)

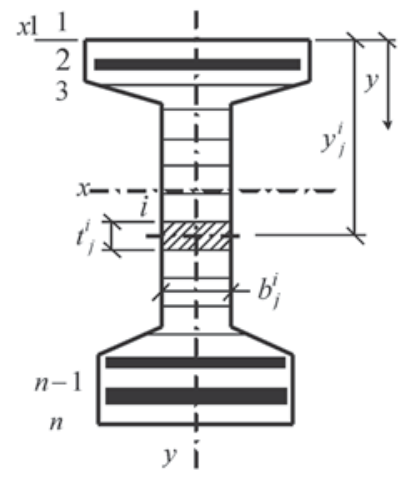

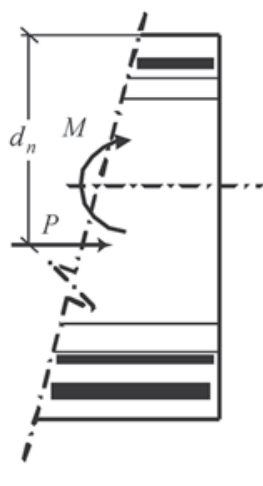

d)

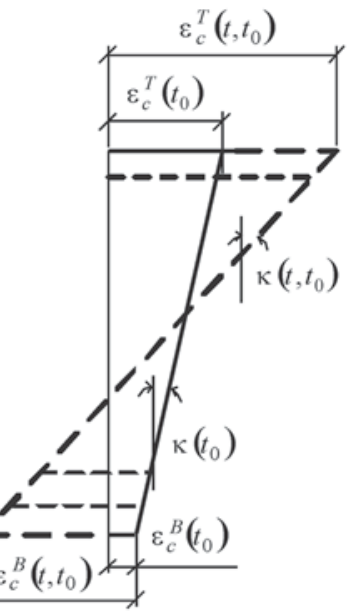

Fig 3. PPC section and strain diagram for short- and long-term loading ( long-term loading 
Table 1. Main characteristics of beams

\begin{tabular}{|c|c|c|c|c|c|c|c|c|c|c|c|c|}
\hline No & Beam & $\begin{array}{l}t_{P} \\
{[\mathrm{~d}]}\end{array}$ & $\begin{array}{c}t_{M} \\
t \\
\text { [d] }\end{array}$ & $\begin{array}{c}b \\
{[\mathrm{~mm}]}\end{array}$ & $\begin{array}{c}h \\
{[\mathrm{~mm}]}\end{array}$ & $\begin{array}{c}d_{s} \\
{[\mathrm{~mm}]}\end{array}$ & $\begin{array}{c}d_{s p} \\
{[\mathrm{~mm}]}\end{array}$ & $\begin{array}{c}a_{s} \\
{[\mathrm{~mm}]}\end{array}$ & $\begin{array}{c}A_{s} \\
{\left[\mathrm{~mm}^{2}\right]}\end{array}$ & $\begin{array}{c}A_{s p} \\
{\left[\mathrm{~mm}^{2}\right]}\end{array}$ & $\begin{array}{c}A_{s}^{\prime} \\
{\left[\mathrm{mm}^{2}\right]}\end{array}$ & $\begin{array}{c}\sigma_{00} \\
{[\mathrm{MPa}]}\end{array}$ \\
\hline 1 & 2 & 3 & 4 & 5 & 6 & 7 & 8 & 9 & 10 & 11 & 12 & 13 \\
\hline 1. & HL20 & \multirow{4}{*}{9} & \multirow{4}{*}{$\begin{array}{c}16 \\
700\end{array}$} & \multirow{4}{*}{200} & \multirow{4}{*}{250} & \multirow{4}{*}{210} & \multirow{4}{*}{160} & - & 397,2 & 80,0 & - & 900,0 \\
\hline 2. & HL22 & & & & & & & 30 & 317,5 & 80,0 & 397,2 & 900,0 \\
\hline 3. & HL30 & & & & & & & - & 253,4 & 128,0 & - & 940,0 \\
\hline 4. & HL32 & & & & & & & 30 & 184,9 & 128,0 & 397,2 & 940,0 \\
\hline 5. & ML20 & \multirow{4}{*}{9} & \multirow{4}{*}{$\begin{array}{c}16 \\
700\end{array}$} & \multirow{4}{*}{200} & \multirow{4}{*}{250} & \multirow{4}{*}{210} & \multirow{4}{*}{160} & - & 397,2 & 80,0 & - & 940,0 \\
\hline 6. & ML22 & & & & & & & 30 & 317,5 & 80,0 & 397,2 & 860,0 \\
\hline 7. & ML30 & & & & & & & - & 253,4 & 128,0 & - & 940,0 \\
\hline 8. & ML32 & & & & & & & 30 & 184,9 & 128,0 & 397,2 & 900,0 \\
\hline
\end{tabular}

$t_{0}, t_{M}$ : ages at prestressing and first loading, respectively

$t:$ duration of the long-term loading

$b, h:$ width and height of cross-section

$d_{s}, d_{s p}, a_{s}^{\prime}:$ distances from the centre of tensile reinforcing bar, prestressing bar and compressive reinforcing bar to the top surface, respectively

$A_{s}, A_{s}^{\prime}, A_{s p}$ : areas of tensile bar, compressive bar and prestressing reinforcement, respectively

$\sigma_{00}:$ initial prestress

Table 2. Properties of concrete

\begin{tabular}{c|c|c|c}
\hline Concrete & $\begin{array}{c}f_{c}(28) \\
{[\mathrm{MPa}]}\end{array}$ & $\begin{array}{c}f_{c t}(28) \\
{[\mathrm{MPa}]}\end{array}$ & $\begin{array}{c}E_{c}(28) \\
{[\mathrm{MPa}]}\end{array}$ \\
\hline Medium-strength & 44,5 & 3,6 & 36,8 \\
\hline High-strength & 105,4 & 6,4 & 38,7 \\
\hline
\end{tabular}

$f_{c}(28), f_{c t}(28), E_{c}(28)$ : compressive (cylinder) and tensile strengths and Young's modulus of concrete at 28 days, respectively

The autogenous shrinkage at early ages in high strength concrete was taken into account, while shrinkage strain of medium-strength concrete before prestressing was neglected. It should be noted that deflections due to autogenous shrinkage in PRHSC before prestressing are not given $[15,16]$.

Measured time-dependent curvatures of partially prestressed middle- and high-strength concrete members are shown in Figs 4-7.

The mean curvatures of PRHSC members corresponding to instaneous loading were by 20 to $40 \%$ smaller in repeat to PRMSC members under sustained loading the difference varied from 30 to $55 \%$. Comparison of computed and measured curvatures are shown in Figs 4-7. The comparison shows a reasonable agreement.

The average test strain in tension steel of cracked members ML22 and ML32 (measured for the pure bending zone) are shown in Figs 8-9, respectively.

The comparison given in Figs 8-9 also shows a fairly good agreement.

It can be noted that the mean curvatures of PRHSC are by $20-40 \%$ smaller at application of instantaneous load and also by $30-55 \%$ smaller after loading than those of PRMSC, respectively (Figs 4-7).

\section{Concluding remarks}

In this paper a simplified approach to computing instantaneous and long-term deformations for both cracked and non-cracked section of reinforced (non-prestressed), prestressed and partially prestressed concrete has been proposed.

The present research further extends the application of the Flexural constitutive model. Cracking, tension stiffening, shrinkage and creep effects have been included in the model. The proposed calculation technique is based on layered approach and the effective modulus method. A unified algorithm has been applied for both short- and long-term analysis.

Acceptability of the proposed calculation technique was checked by estimating curvatures and steel strains for eight experimental partially prestressed high- and middle-strength concrete members reported in the literature $[15,17,18]$

The autogeneous shrinkage at early ages in highstrength concrete was taken into account in the analysis. The characteristics of concrete creep facts and free shrinkage strain were taken from the tests. Comparison of the computed and measured data has shown a reasonable agreement. 


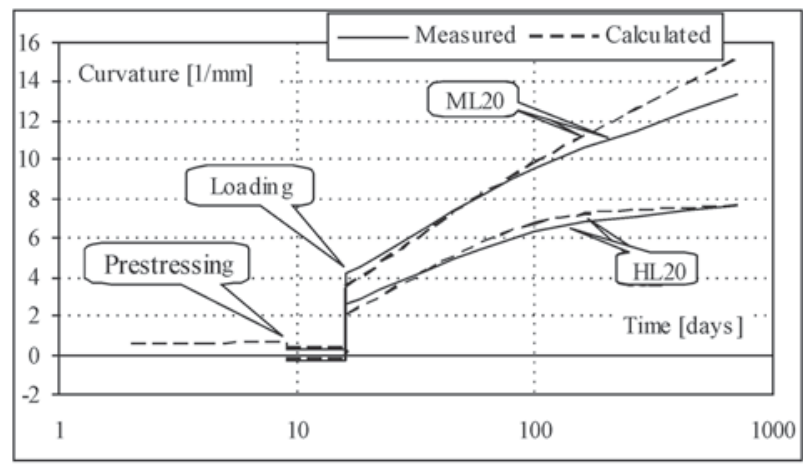

Fig 4. Comparison of HL20 and ML20 for time-dependent curvatures

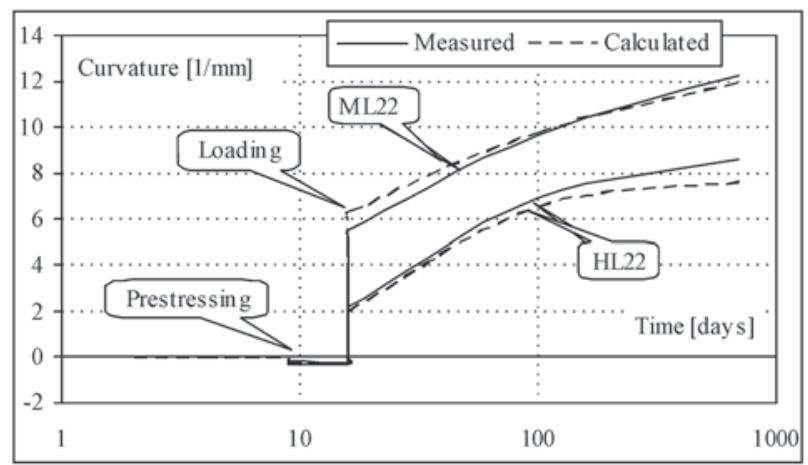

Fig 5. Comparison of HL22 and ML22 for time-dependent curvatures

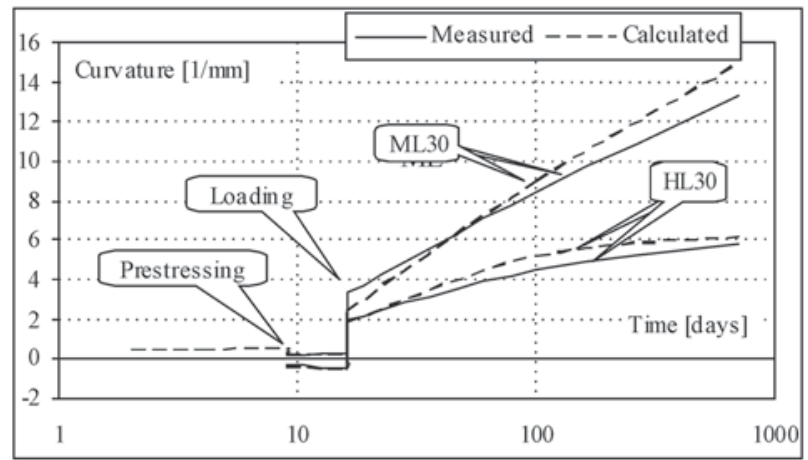

Fig 6. Comparison of HL30 and ML30 for time-dependent curvatures

\section{References}

1. Pre-cast/Prestressed Concrete Institute. PCI Design Handbook. Pre-cast and Prestressed Concrete. Fourth edition. PCI Industry Handbook Committee. Chicago, Illinois. 1992. 350 p.

2. Eurocode 2: Design of Concrete Structures - Part 1: General Rules and Rules for Buildings. European Committee for Standardization. Pr-EN 1992-1, October 2001. 230 p.

3. SNiP 2.03.01-84. Building Code: Concrete and Reinforced Concrete Structures (СНИП 2.03.01-84*. Бетонные и железобетонные конструкции. Строительные нормы и правила). Moscow: Gosstroj SSSR, 1985. 71 p. (in Russian).

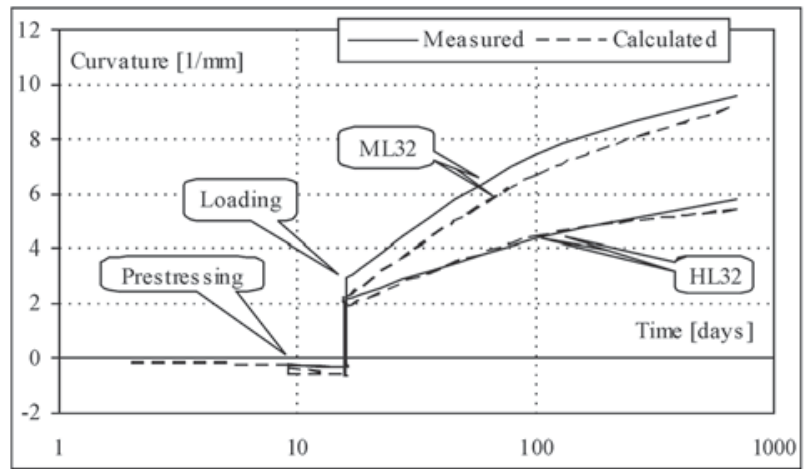

Fig 7. Comparison of HL32 and ML32 for time-dependent curvatures

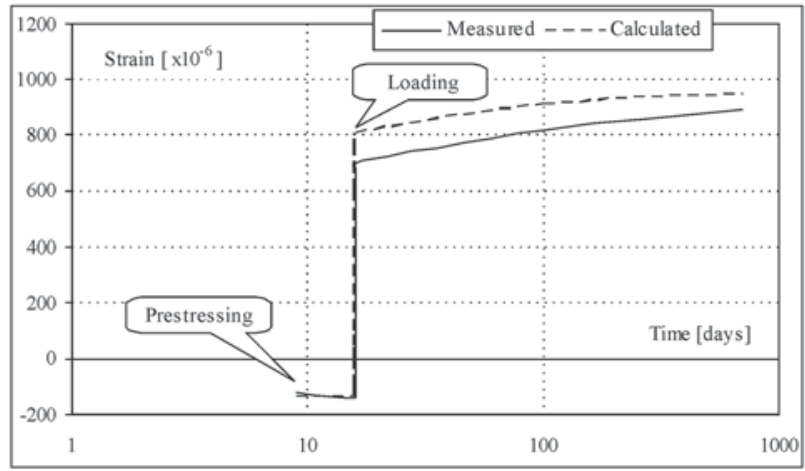

Fig 8. Comparison of ML22 for time-dependent strain in tensile reinforcing bar

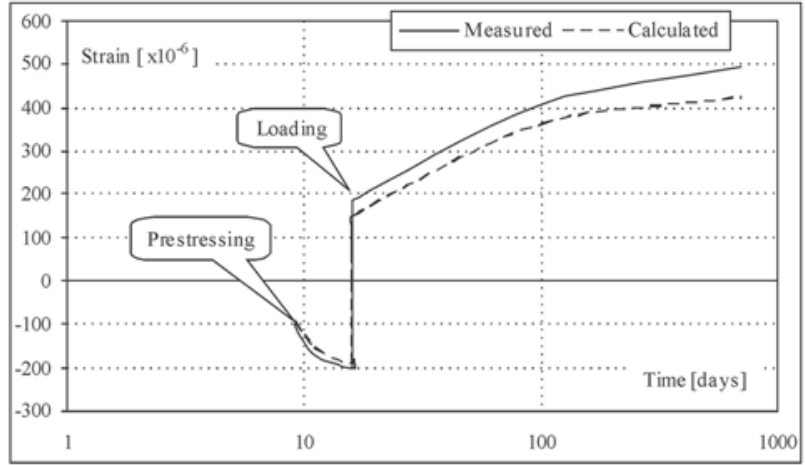

Fig 9. Comparison of ML32 for time-dependent strain in tensile reinforcing bar

4. CEB-FIP Model Code 90. Comite Euro-International du Beton - Federation Internationale de la Precontrainte, Ed Thomas Telford, London, 1993.

5. Cervenka, V. Computer Simulation of Failure of Concrete Structures for Practice. In: Proccedings of the First fib Congress, Concrete Structures in the 21st Century, Osaka, Oct 13-19, 2002, p. 289-304.

6. Fanning, P. Nonlinear Models of Reinforced and PostTensioned Concrete Beams. Electronic Journal of Structural Engineering, Vol 1, 2001, p. 111-119.

7. Kawakami M., Ito T. Non-linear Finite Element Analysis of Prestressed Concrete Members In: Proceedings of the 
First fib Congress, Concrete Structures in the 21st Century, Osaka, Oct 13-19, 2002, p. 261-270.

8. Kaklauskas, G. Integral Flexural Constituve Model for Deformational Analysis of Concrete Structures. Monograph. Vilnius: Technika, 2001. 140 p.

9. Kaklauskas, G. Flexural Layered Deformational Model of Reinforced Concrete Members. Magazine of Concrete Research, Vol 56, No 10, Dec 2004, p. 575-584.

10. Bacinskas D. Integral Model for Long-Term Deformational Analysis of Flexural Reinforced Concrete Members (Lenkiamujų gelžbetoninių elementų ilgalaikio deformavimo integralinis modelis). PhD thesis, Vilnius Gediminas Technical University. Vilnius, 2002. 103 p. (in Lithuanian).

11. Kaklauskas, G.; Christiansen, M. B. Long-Term Deformations of Reinforced Concrete Members. Bygningsstatiske meddelelser, Vol 73, No 4. Danish Society for Structural Science and Engineering. 2002, p. 79-110.

12. Zamblauskaitè, R.; Kaklauskas, G.; Bačinskas, D. and Christiansen, M. B. Short-Term Deformational Analysis of Prestressed Concrete Beams. Journal of Civil Engineering and Management, Vol IX, No 4. Vilnius: Technika, 2003, p. 280-283.
13. Iravani, S. and McGregor, J. G. Sustained Load Strength and Short-Term Strain Behavior of High-Strength Concrete. ACI Material Journal, Vol 95 (5), 1998, p. 636-647.

14. Shkoukani, H. and Walraven, J. Sustained Tensile Strength of Concrete. IABSE Colloqium "Structural Concrete", Vol 62, Stuttgart, 1991, p. 725-729.

15. Sato, R.; Tezuka, M. and Anzai, S. Deformation and Crack Width of Prestressed Reinforced High Strength Concrete Members. In: Proceedings of fib Symposium, Structural Concrete, Prague, 1999, p. 598-606.

16. Tezuka, M.; Sato, R.; Xu, M. and Sodeyama, T. On Applicability of Long-Term Effective Flexural Rigidity Equations for High Strength Concrete Members. In: Proceedings of the Japan Concrete Institute, Vol 20, No 3, 1998, p. 247-252 (in Japanese).

17. Sato, R.; Hirokawa, K.; Ujike, I. and Anzai, S. Numerical Analysis of Concrete Members Based on the Superposition Principle for Creep of Concrete and Bond. In: Proceedings of fib Symposium, Structural Concrete, Prague, 1999, p. 417-423.

18. Yang, Y.; Xu, M.; Sato, R. and Tezuka, M. Experimental Investigation on Shrinkage and Creep of High Strength Concrete at Early Ages. In: Proceedings Fourth CANMET/ ACI/JCI. 1998, p. 201-215.

\section{STIPRIOJO IR VIDUTINIO STIPRIO BETONO IৃTEMPTŲJŲ LENKIAMŲJŲ GELŽBETONINIŲ ELEMENTŲ DEFORMACIJŲ ANALIZE் PAGAL INTEGRALINI MODELI}

\section{R. Zamblauskaitė, G. Kaklauskas, D. Bačinskas}

Santrauka

Analizuojamos stipriojo ir vidutinio stiprio betono įtemptujų lenkiamujų gelžbetoninių elementų trumpalaikès bei ilgalaikès deformacijos taikant integralinị modelį. Integruotai įvertintos betono valkšnumo ir traukimosi deformacijos bei tempiamojo betono pleišèjimas ir elgsena tarp plyšių. Pasiūlytas trumpalaikių bei ilgalaikių deformacijų skaičiavimo modelis, pagrisstas sluoksnių bei efektyviojo modulio metodais. Taikant pasiūlytają metodiką, eksperimentinių sijų kreiviai palyginti su apskaičiuotaisiais.

Raktažožiai: betono valkšnumo ir traukimosi deformacijos, mišriai armuotas įtemptasis gelžbetoninis elementas, išankstinio itempimo nuostoliai, supleišèjusio elemento tempiamojo betono tarp plyšiu darbas, lenkimas, kreivis.

Renata ZAMBLAUSKAITĖ. PhD student of the Dept of Bridges and Special Structures at Vilnius Gediminas Technical University. MSc (2001, civil engineer) at VGTU. Research interests: deformation of reinforced and prestressed concrete structures.

Gintaris KAKLAUSKAS. Professor and Head of Dept of Bridges and Special Structures at Vilnius Gediminas Technical University, Lithuania. PhD and Dr Habil at VGTU. Recipient of Fulbright Fellowship (for research work at the University of Illinois, Urbana-Champaign, 1996) and Marie Curie Fellowship (experienced researcher category, 20022003). Member of the FIB Task Group 4.1 "Serviceability Models". Research interests: various topics of reinforced concrete, particularly constitutive modelling and numerical simulation of reinforced concrete structures.

Darius BAČINSKAS. Associate Professor of Dept of Bridges and Special Structures at Vilnius Gediminas Technical University, Lithuania. PhD (2002) at VGTU. Research interests: material constitutive models, non-linear numerical analysis of reinforced concrete structures. 